\title{
Refleksi Teologis Solidaritas Menurut Mgr. Johannes Pujasumarta dalam Terang Ajaran Sosial Gereja
}

\author{
Yohanes Yayan Riawan a,1 \\ Program Magister Teologi Fakultas Teologi Universitas Sanata Dharma ${ }^{a}$ \\ johnyayan16@gmail.com ${ }^{1}$
}

\section{Keywords:}

Solidaritas, Kaum miskin, Allah Pencipta, Allah Penyelamat, Iman,

Kebersamaan,

Kesejahteraan umum (bonum commune), Praksis hidup.

\begin{abstract}
Solidarity is a process of partiality of the attitudes and views of the Church, namely care for those who are weak and poor and excluded from the formulation of preferential options for the poor. Solidarity have to return to the gospel, learn from Jesus himself who proclaimed God's Kingdom, is present and involved in the world. In solidarity man finds God, the Creator, in his fellow creatures and nature. Solidarity finally changes people in three ways, namely the perception of God, the praxis of life, and the life of prayer which all lead to one and the same thing that is God - The Creator who has saved all creation. Solidarity must be manifested in the praxis of daily life in favor of the poor and oppressed.
\end{abstract}

\section{PENGANTAR}

Badan Pusat Statistik (BPS) memberikan data persentase penduduk miskin di Indonesia per September 2019. ${ }^{1}$ Persentase penduduk miskin pada September 2019 sebesar 9,22 persen, menurun 0,19 persen poin terhadap Maret 2019 dan menurun 0,44 persen poin terhadap September 2018. Jumlah penduduk miskin pada September 2019 sebesar 24,79 juta orang, menurun 0,36 juta orang terhadap Maret 2019

BPS, "Persentase Penduduk Miskin September 2019 turun menjadi 9,22 persen" (15 Januari 2020), tersedia dari https:// www.bps.go.id/pressrelease/2020/01/15/1743/persentasependuduk-miskin-september-2019-turun-menjadi-9-22persen.html; diakses 20 Januari 2020. dan menurun 0,88 juta orang terhadap September 2018. Persentase penduduk miskin di daerah perkotaan pada Maret 2019 sebesar 6,69 persen, turun menjadi 6,56 persen pada September 2019. Sementara persentase penduduk miskin di daerah perdesaan pada Maret 2019 sebesar 12,85 persen, turun menjadi 12,60 persen pada September 2019. Dibanding Maret 2019, jumlah penduduk miskin September 2019 di daerah perkotaan turun sebanyak 137 ribu orang (dari 9,99 juta orang pada Maret 2019 menjadi 9,86 juta orang pada September 2019). Sementara itu, daerah perdesaan 
turun sebanyak 221,8 ribu orang (dari 15,15 juta orang pada Maret 2019 menjadi 14,93 juta orang pada September 2019). Garis Kemiskinan pada September 2019 tercatat sebesar Rp440.538,-/ kapita/bulan dengan komposisi Garis Kemiskinan Makanan sebesar Rp324.911,- (73,75 persen) dan Garis Kemiskinan Bukan Makanan sebesar Rp115.627,- (26,25 persen). Pada September 2019, secara rata-rata rumah tangga miskin di Indonesia memiliki 4,58 orang anggota rumah tangga. Dengan demikian, besarnya Garis Kemiskinan per rumah tangga miskin secara rata-rata adalah sebesar Rp2.017.664,-/rumah tangga miskin/bulan.

Dari data BPS tersebut, tampak bahwa di Indonesia kemiskinan masih menjadi suatu masalah yang aktual pada zaman ini. Di berbagai tempat, tingkat kesejahteraan terus bertumbuh, namun juga terdapat fakta yang memprihatinkan terkait jumlah orangorang yang miskin karena berbagai alasan. Kesenjangan antara mereka yang miskin dan yang kaya cukup lebar. ${ }^{2}$ Di tengah realitas kemiskinan tersebut, dunia saat ini mengalami kemajuan di berbagai bidang kehidupan, yang dikenal dengan istilah era globalisasi. Kemajuan ini membawa perubahan dalam seluruh bidang kehidupan

\footnotetext{
Badan Pusat Statistik (BPS) melansir tingkat ketimpangan pengeluaran penduduk yang tercermin dari rasio gini berada di posisi 0,382 pada Maret 2019. Semakin tinggi angka rasio gini, berarti ketimpangan semakin melebar. Sebaliknya, kalau angka rasio gini mengecil, maka ketimpangannya semakin kecil. Ketimpangan yang lebar menandakan bahwa ketidakmerataan pengeluaran masyarakat. Di dalam menghitung rasio gini, BPS menggunakan standar yang digunakan Bank Dunia yakni membagi distribusi pengeluaran masyarakat dalam ketiga kelompok. Ketiga kelompok itu terdiri dari 40 persen masyarakat dengan pengeluaran rendah, 40 persen masyarakat pengeluaran menengah, dan 20 persen masyarakat pengeluaran tinggi. Dari hasil perhitungan BPS, $45,48 \%$ pengeluaran masyarakat Indonesia masih dilakukan oleh golongan kaya. Sementara itu, pengeluaran golongan masyarakat tidak mampu hanya 17,71\% dari total pengeluaran masyarakat Indonesia antara Maret hingga September 2018. (CNN, "Ketimpangan antara Si Kaya dan Si Miskin Menciut" - 15 Juli 2019), tersedia dari https://www.cnnindonesia.com/eko nomi/20190715150830-532-412253/ketimpangan-antara-sikaya-dan-si-miskin-menciut; diakses 20 Januari 2020).
}

manusia baik informasi, teknologi, transportasi, cara pandang kepada Allah, dunia dan sesama manusia. Kemajuan ini tentunya memberikan efek positif, namun ada pula efek negatifnya. Keegoisan dan ketamakan dalam diri manusia membuat kehidupan ini yang seharusnya ditandai oleh kasih, solidaritas atau kebersamaan yang dinyatakan melalui tindakan nyata untuk menolong orang lain yang mengalami berbagai penderitaan semakin hilang.

Agama Kristiani (Gereja Katolik) di tengah situasi dunia yang demikian ditantang untuk menunjukkan identitasnya sebagai agama yang didasarkan oleh kasih, yang diwujudnyatakan melalui sikap peduli dan solider kepada mereka yang miskin dan menderita dengan cara ikut menentang ketidakadilan dan menyuarakan hak-hak kaum lemah dan tertindas. Gereja terpanggil untuk bersuara dan bertindak, berpihak kepada yang miskin, lemah, dan tertindas sebagai manifestasi kesaksian dan pelayanan di tengah-tengah dunia ini. Dengan keterlibatan ini, Gereja dapat menunjukkan solidaritasnya secara nyata. Solidaritas telah menjadi wacana pokok berkaitan dengan keprihatinan dan kepedulian Gereja Katolik terhadap kehidupan manusia masa kini, yang ditandai oleh kenyataan yakni adanya kemiskinan dan ketidakadilan, jurang antara yang kaya dan yang miskin, kerusakan alam, persoalan perubahan iklim, dll. Kenyataan ini tentu saja menjadi tantangan bagi Gereja pada hal kemanusiaan, serta keutuhan ciptaan.

Solidaritas menjadi salah satu nilai utama yang dihidupi oleh Gereja Katolik dan Gereja Keuskupan Agung Semarang (KAS) pada khususnya. Solidaritas tersebut dinyatakan melalui pemberdayaan kaum Kecil, Lemah, Miskin, Tersingkir, dan 
Difabel (KLMTD). Keberpihakan Gereja Keuskupan Agung Semarang kepada kaum KLMTD nampak pada Arah Dasar KAS yang dibuat sebagai acuan dasar dalam berpastoral, sebagai sebuah usaha untuk mewujudkan Gereja Keuskupan Agung Semarang yang semakin signifikan dan relevan bagi umat dan masyarakat. Keuskupan Agung Semarang memiliki citacita untuk semakin mengikuti Yesus Kristus dengan mengusahakan terciptanya tatanan hidup demi kesejahteraan semua orang dengan mengutamakan saudara-saudara yang miskin, lemah dan menderita. ${ }^{3}$

Arah Dasar Keuskupan Agung Semarang 2006-2010 menempatkan mereka yang kecil, lemah, miskin, dan tersingkir sebagai pelaku pembaruan menuju habitus baru dengan cara memberdayakannya. ${ }^{4}$ Arah Dasar Keuskupan Agung Semarang tahun 2011-2015 juga menampakkan nilai solidaritas dalam langkah pastoral yang ditempuh untuk pengembangan umat Allah, terutama optimalisasi peran kaum awan secara berkesinambungan dan terpadu dalam perwujudan iman di tengah masyarakat: pemberdayaan kaum kecil, lemah, miskin, tersingkir, dan difabel; serta pelestarian keutuhan ciptaan alam. Terkait dengan hal-hal tersebut Gereja yang merupakan bagian dari masyarakat ingin memberikan perhatiannya kepada kaum miskin. Karena itulah Gereja menunjukkan keberpihakannya kepada kaum miskin dengan mengambil pilihan mendahulukan kaum miskin (option for the poor).

Mgr. Johannes Pujasumarta sebagai tokoh Gereja Keuskupan Agung Semarang memberikan perhatian khusus pada kaum

\footnotetext{
M. Nur Widi, Eklesiologi ARDAS Keuskupan Agung Semarang, (Yogyakarta: Kanisius, 2009) 11.

4 M. Nur Widi, Eklesiologi ARDAS Keuskupan Agung Semarang, 120.
}

kecil, lemah, miskin, tersingkir, dan difabel, hubungan dengan agama lain, dan keutuhan ciptaan dengan menawarkan nilai solidaritas yang nampak dalam penggembalaan beliau saat menjadi Uskup Keuskupan Agung Semarang (periode 2011-2015 bersamaan dengan ARDAS KAS 2011-2015). Dalam masa penggembalaannya, Mgr. Johannes Pujasumarta menampakkan nilai solidaritas yang khas, khususnya melalui pemikiran beliau yang tertuang dalam Surat-surat Gembala yang beliau tulis selama menjabat sebagai Uskup KAS.

\section{SOLIDARITAS MENURUT MGR. JOHANNES PUJASUMARTA}

Dalam menanggapi berbagai permasalahan dan tantangan yang ada di masyarakat dan dalam Gereja Keuskupan Agung Semarang sendiri, Mgr. Johannes Pujasumarta sebagai gembala umat menyampaikan tanggapan dan ajaran melalui Surat Gembala. Dalam surat-surat gembala yang beliau tulis, beliau banyak memberikan perhatian dalam hal solidaritas. Setidaknya ada lima poin mengenai gagasan solidaritas yang beliau ajarkan melalui surat-surat gembalanya. Gagasan-gagasan solidaritas tersebut adalah Solidaritas sebagai Perwujudan Iman Katolik; Solidaritas sebagai Wajah Gereja Papa Miskin; Solidaritas sebagai Persaudaraan Sejati; Solidaritas sebagai Harmonisasi dengan Alam Ciptaan; serta Solidaritas sebagai Semangat Nasionalisme.

\section{Solidaritas sebagai Perwujudan Iman}

Iman akan Yesus Kristus menjadi nafas hidup menggereja dan menjadi pola hidup Kristiani. Konsekuensi dari pola hidup Kristiani adalah iman akan Yesus Kristus tersebut harus menjadi landasan hidup bersama di dalam masyarakat. Kekatolikan 
tidak hanya sekedar nama baptis yang melengkapi nama diri, bukan keterangan agama yang tercantum pada Kartu Tanda Penduduk (KTP), bukan pula pada cara berdoanya. Iman yang mendalam tidak hanya sebatas dalam doa dalam tata liturgi, namun juga terwujud dalam tindakan nyata. Menurut Mgr. Johannes Pujasumarta, kesejatian iman Katolik tersebut terletak pada rahmat sehingga mampu melakukan kehendak Bapa. ${ }^{5}$ Iman bukanlah hal yang semata-mata abstrak dan mengawangawang, namun harus diwujudnyatakan. Iman masuk dan sungguh disadari dalam berbagai peristiwa hidup manusia di tengah masyarakat. ${ }^{6}$ Dengan jati diri sebagai orang Katolik sejati, maka umat Katolik Keuskupan Agung Semarang juga diharapkan peduli dan rela berbagi. ${ }^{7}$ Iman akan Yesus Kristus menjadi landasan umat Kristiani dalam melaksanakan pangilan dan perutusannya di tengah dunia.

\section{Solidaritas sebagai Wajah Gereja Papa Miskin}

Adanya kenyataan bahwa kehidupan manusia saatini dipenuhidengan kemiskinan, kekerasan, ketidakadilan, dan tindakantindakan lain yang tidak menghormati martabat manusia, Gereja menyatakan keberpihakannya kepada kaum miskin. ${ }^{8}$ Gereja Keuskupan Agung Semarang sebagai bagian dari masyarakat yang berhadapan langsung dengan kenyataan masyarakat lokal juga menampilkan keberpihakannya kepada kaum miskin. Keberpihakan Gereja kepada kaum papa miskin mengajak umat

J. Pujasumarta, Surat Gembala Prapaskah 2011: Orang Katolik Sejati Melakukan Kehendak Bapa, 25 Februari 2011.

6 J. Pujasumarta, Surat Gembala Prapaskah 2011: Orang Katolik Sejati Melakukan Kehendak Bapa.

J. Pujasumarta, Surat Gembala Prapaskah 2014: Allah Peduli dan Kita Menjadi Perpanjangan Tangan Kasih-Nya untuk Melayani, 22 Februari 2014.

8 J. Pujasumarta, Surat Gembala Hari Pangan Sedunia 2011 Kamu Harus Memberi Mereka Makan, 25 September 2011. untuk berbuat sesuatu yaitu memberikan perhatian dan menggerakkan umat untuk bersolider. Keberpihakan kepada kaum miskin tidak harus dengan hal-hal yang besar. Melalui hal yang sangat kecil dan sederhana pun umat bisa memberikan perhatian dan mewujudkan solidaritasnya. Mgr. Johannes Pujasumarta menegaskan akan jati diri Gereja Keuskupan Agung Semarang sebagai Gereja Papa Miskin. ${ }^{9}$

Mgr. Johannes Pujasumarta ingin menegaskan dan mengingatkan bahwa Gereja Keuskupan Agung Semarang benar-benar memberikan perhatian dan kepeduliannya kepada kaum miskin. Perhatian Gereja kepada kaum papa miskin menjadi prioritas pelayanan di Keuskupan Agung Semarang yaitu sebagai wujud nyata bahwa Gereja benar-benar berada di tengah masyarakat dan berusaha membawa dunia ke arah yang lebih bermartabat dan lebih baik.

\section{Solidaritas sebagai Bentuk Persaudaraan Sejati}

Dalam kehidupan bersama di tengah masyarakat dengan berbagai keragamannya, termasuk juga keberagaman dalam hal agama dan kepercayaan, dialog antar agama dianggap sebagai hal yang penting dan menjadi salah satu fokus dalam pembinaan hidup beriman. Hidup beriman tidak sekedar tentang hidup doa, dan olah rohani. Dalam perkembangannya hidup beriman pun mendorong para pemeluk agama untuk memiliki pandangan yang terbuka terkait dengan hubungannya dengan pemeluk agama dan kepercayaan lain.

Mgr. Johannes Pujasumarta mengajak umat Keuskupan Agung Semarang untuk

\footnotetext{
9 J. Pujasumarta, Surat Gembala Prapaskah 2015: Iman Disertai Perbuatan Kasih Semakin Hidup, 2 Februari 2015.
} 
menyadari identitasnya sebagai muridmurid Yesus Kristus. ${ }^{10}$ Dengan panggilan sebagai murid-murid Yesus Kristus tersebut, Mgr. Johannes Pujasumarta mengajak umat Katolik Keuskupan Agung Semarang menjadi tanda perdamaian. Terlebih dalam kehidupan sehari-hari setiap manusia memerlukan orang lain untuk memenuhi kebutuhan hidupnya. Itulah tanda bahwa manusia adalah makhluk sosial. Relasi yang muncul tersebut menjadi sarana persaudaraan sejati dengan semua orang.

Keharmonisan yang pada dasarnya berasal dari komunikasi dan relasi, ketika hancur perlu dibenahi dan ditata kembali, itulah dialog. Rasa persaudaraan dapat ditumbuhkembangkan dengan dialog diskusi yang membicarakan pokok-pokok iman agama lain. Diskusi ini bertujuan untuk memberikan pemahaman baru yang terkait dengan agama dan kepercayaan lain sehingga mampu untuk menghormati pemikiran dan paham agama lain. Dialogjuga dapat dilakukan dengan dialog karya. Dialog karya yang dimaksud adalah kerjasama yang dibangun antara orang Katolik dengan orang yang beragama dan berkepercayaan lain. Kerjasama tersebut dapat berupa kerjasama dalam hal sosial kemasyarakatan seperti kerja bakti, bakti sosial, dll. Hal lain juga dapat melalui kerjasama dalam hal kesenian dan kebudayaan. Melalui segi-segi kehidupan manusiawi, dialog karya dapat berjalan dan diusahakan. ${ }^{11}$ Dalam kehidupan bersama di tengah masyarakat dengan keberagaman iman, agama, dan keyakinan, umat Katolik Keuskupan Agung Semarang didorong untuk

\footnotetext{
10 J. Pujasumarta, Surat Gembala Hari Minggu Hubungan Antaragama dan Kepercayaan, 20 Januari 2013.

11 J. Pujasumarta, Surat Gembala Hari Minggu Hubungan Antaragama dan Kepercayaan 2014: Merajut Persaudaraan Sejati Lintas Iman - Menghadirkan Kasih Tuhan, 20 Januari 2014.
}

menjaga persaudaraan yang sejati. Semakin membangun dialog dan kerjasama dalam berbagai hal dengan mereka yang memiliki agama dan kepercayaan lain.

\section{Solidaritas sebagai Wujud Harmonisasi dengan Alam Ciptaan}

Melestarikan keutuhan alam ciptaan juga menjadi salah satu bagian dalam kehidupan menggereja. Selain memberikan perhatian kepada manusia khususnya mereka yang kecil lemah, miskin, tersingkir, dan difabel, Gereja juga berusaha untuk memberikan perhatian terhadap alam ciptaan yang merupakan bagian dari hidup manusia. ${ }^{12}$ Perhatian terhadap alam ciptaan merupakan bagian dari peristiwa hidup manusia dan diharapkan pula dapat membawa umat Katolik untuk tumbuh dan berkembang dalam iman yang mendalam dan tangguh. Menjaga keutuhan alam ciptaan juga menjadi salah satu sarana dalam upaya menjaga komunikasi dan hubungan antaragama dan kepercayaan. Dalam menjaga keharmonisan dalam hidup bersama antaragama dan kepercayaan, dialog karya yang dapat dilakukan adalah dengan kerjasama untuk menjaga keutuhan alam ciptaan. ${ }^{13}$ Hal ini menandakan bahwa perhatian untuk menjaga keutuhan lingkungan hidup tidak hanya menjadi perhatian dari Gereja Katolik namun juga menjadi perhatian bersama. Dengan demikian dapat dikatakan bahwa antara menjaga keutuhan alam ciptaan dengan hubungan antaragama dan kepercayaan memiliki keterkaitan yaitu salah satu sarana untuk terjalinnya keharmonisan antaragama dan kepercayaan.

\footnotetext{
12 J. Pujasumarta, Surat Gembala Hari Pangan Sedunia 2011: Kamu Harus Memberi Mereka Makan.

13 J. Pujasumarta, Surat Gembala Hari Minggu Hubungan Antaragama dan Kepercayaan 2013.
} 
Mgr. Johannes Pujasumarta menyampaikan bahwa usaha menjaga keutuhan alam ciptaan menjadi sebuah pertobatan rohani ${ }^{14}$ dalam menghargai bumi sebagai salah satu ciptaan Allah, menjadikan bumi sebagai rahim pangan milik bersama. Pertobatan ekologis yang didasarkan pada kesadaran bahwa keseimbangan alam ciptaan telah berubah karena perbuatan manusia yang kurang memberikan perhatian pada pemeliharaan alam ciptaan. Dengan pertobatan tersebut umat Katolik diajak untuk kembali menyadari perannya di dunia yaitu sebagai teman sekerja Allah dalam merawat bumi. Allah yang telah menciptakan selama sesuatu dengan baik adanya ingin mengajak manusia untuk menyadari bahwa manusia diciptakan serupa dan segambar dengan Allah. Karena itu, sudah sepatutnya manusia menjadi rekan sekerja Allah dalam merawat bumi.

\section{Solidaritas sebagai Semangat Nasionalisme}

Sebagai bagian dari bangsa Indonesia, Gereja Keuskupan Agung Semarang juga memberikan perhatiannya dalam membangun bangsa dan negara Indonesia. Ini merupakan salah satu panggilan Gereja dalam mengusahakan bonum commune. Mgr. Johannes Pujasumarta mengajak umat Katolik Keuskupan Agung Semarang untuk mensyukuri kemerdekaan Indonesia sebagai rahmat yang diberikan Tuhan kepada bangsa Indonesia. Dengan rahmat tersebut umat Katolik didorong untuk menjadi pelopor dalam mencintai negara Indonesia. ${ }^{15}$ Walau bangsa Indonesia sudah terlepas dari penjajahan bangsa lain, pada

\footnotetext{
14 J. Pujasumarta, Surat Gembala Hari Pangan Sedunia 2015 Bumi sebagai Rahim Pangan Milik Bersama, 8 September 2015.

15 J. Pujasumarta, Surat Gembala HUT Kemerdekaan Ke-67 Republik Indonesia, 10 Agustus 2012.
}

kenyataannya saat ini bangsa Indonesia masih dalam nuansa 'penjajahan' yaitu berupa kemiskinan dan kebodohan. Berbagai permasalahan ekonomi, ketimpangan sosial karena kemajuan dan fasilitas negara hanya bisa dinikmati oleh golongan tertentu, dan tindakan intoleransi yang memecah kesatuan bangsa membuat keprihatinan tersendiri dalam diri Gereja.

Mgr. Johannes Pujasumarta mengajak umat Katolik untuk selalu mengusahakan keadilan dan kesejahteraan. Keadilan dan kesejahteraan tersebut diupayakan demi terwujudnya peradaban kasih. $^{16}$ Mgr. Pujasumarta menawarkan beberapa upaya dan ajakan untuk membangun peradaban kasih di bumi Indonesia, yaitu ${ }^{17}$, pertama, sejak dalam keluarga perlu ditumbuh kembangkan rasa cinta kepada sesama dan lingkungan kehidupan, agar anak-anak yang kita cintai hidup dalam "peradaban kasih", memilikirasa handarbeni (rasa memiliki) dan memiliki negeri ini; kedua, lembaga-lembaga pendidikan formal perlu mengajarkan pendidikan kebangsaan dan "pendidikan peradaban kasih" yang terencana sebagai isi dari "Sekolah Cinta Kasih", agar memahami nilai-nilai dasar Pancasila dan Ajaran Sosial Gereja; ketiga, Bidang-bidang pelayanan dalam Dewan Paroki memberikan ruang dan perhatian khusus bagi kaderisasi agar umat Katolik siap sedia menjadi patriot sejati; keempat, masyarakat sebagai tempat tumbuh dan berkembangnya pribadi perlu mengembuskan atmosfer yang mendukung suasana kehidupan berbangsa dan bernegara yang baik dan benar. Semboyan Bhinneka Tunggal Ika juga menjadi pengikat dalam upaya mengembangkan persaudaraan antar

\footnotetext{
16 J. Pujasumarta, Surat Gembala Hari Raya Kemerdekaan RI ke-68: Mengisi Kemerdekaan dengan Peradaban Kasih, 15 Agustus 2013

17 Y. Gunawan, Menghidupi Teologi Berkah Bersama Johannes Pujasumarta, (Yogyakarta: Kanisius 2018), 186.
} 
warga negara. Dengan menjadi pelopor dalam mencintai bangsa dan negara Indonesia, umat Katolik Keuskupan Agung Semarang diajak untuk menciptakan optimisme diri dalam membangun harapan masa depan bangsa yang benar-benar merdeka dan terbebas dari kemiskinan dan tidak terjebak dalam kemerdekaan semu. ${ }^{18}$

\section{SOLIDARITAS MENURUT MGR. JOHANNES PUJASUMARTA DALAM TERANG AJARAN SOSIAL GEREJA}

Pemikiran Mgr. Johannes Pujasumarta mengenai solidaritas pada dasarnya bertitik tolak pada penghargaan terhadap martabat manusia. Gagasan solidaritas beliau juga mempunyai arti tekad dan keterlibatan setiap pribadi untuk mewujudkan kebaikan bersama (bonum commune). Solidaritas bukan sekedar pilihan bebas manusia, tetapi solidaritas mempunyai dasar sebagai pilihan iman demi pewartaan Kerajaan Allah. Solidaritas merupakan salah satu nilai penting dalam kehidupan Gereja. Karena itu, solidaritas tidak boleh berhenti pada teori semata, tetapi harus diwujudkan dan dihidupi dalam pelayanan pastoral Gereja.

\section{Solidaritas Bersumber pada Martabat Manusia}

Kata "martabat" memiliki arti pangkat atau derajat yang dimiliki manusia sebagi manusia. Dengan memiliki martabat ini manusia menjadi beda dengan makhluk lain ${ }^{19}$. Kata martabat juga memiliki arti tingkat, derajat, pangkat, dan harga diri, sedangkan kata manusia sendiri memiliki arti, manusia yang berakal budi ${ }^{20}$. Martabat

\footnotetext{
8 J. Pujasumarta, Surat Gembala HUT Kemerdekaan Ke-67 Republik Indonesia,.

19 Frans Magnis-Suseno, Berfilsafat dari Konteks, Jakarta: Gramedia, 1991), 95.

20 DEPDIKNAS, Kamus Besar Bahasa Indonesia, Jakarta: Pusat Bahasa, 2008), 917-920.
}

manusia adalah dasar dan hak asasi yang dimiliki oleh setiap orang yang berasal secara kodrati dari Allah.

Manusia diciptakan Allah menurut gambar dan citra-Nya ("Berfirmanlah Allah: Baiklah Kita menjadikan manusia menurut gambar dan rupa Kita, supaya mereka berkuasa atas ikan-ikan di laut dan burungburung di udara dan atas ternak dan atas seluruh bumi dan atas segala bintang melata yang merayap di bumi" - Kej 1:26). Karena manusia diciptakan seturut dengan citra Allah, maka ia mempunyai nilai dan martabat dalam dirinya sebagai pribadi yang dicintai dan dihargai oleh Allah, terlepas dari semua kualifikasi dan keterampilan serta pelbagai unsur lahiriah yang melekat pada manusia. Manusia sebagai gambar dan citra Allah pada hakekatnya bersumber pada Allah, Sang Penciptanya. Karena itu martabat manusia merupakan suatu yang kudus dan suci. Menghormati martabat seseorang sebagai manusia adalah juga menghormati kedaulatan Allah yang berdaulat.

Dalam dokumen Konsili Vatikan II, secara khusus di dalam Gaudium tt Spes (GS) art. 12-17, terdapat beberapa pokok yang menjelaskan mengenai martabat pribadi manusia. Di antaranya adalah pandangan tentang manusia sebagai makhluk yang diciptakan menurut gambar Allah, ${ }^{21}$ situasi keberdosaan manusia,22 kodrat "jiwa" dan "badan" manusia, ${ }^{23}$ martabat akal budi, kebenaran dan kebijaksanaan, ${ }^{24}$ martabat hati nurani ${ }^{25}$ dan tentang keluhuran kebebasan manusia. ${ }^{26}$ Pokok-pokok tersebut sama sekali tidak bertentangan dengan

\begin{tabular}{ll}
\hline 21 & Bdk. GS art. 12. \\
22 & Bdk. GS art. 13. \\
23 & Bdk. GS art. 14. \\
24 & Bdk. GS art. 15. \\
25 & Bdk. GS art. 16. \\
26 & Bdk. GS art. 17.
\end{tabular}


dasar-dasar iman dalam Kitab Suci. Justru semuanya lahir dari Kitab Suci sebagai Wahyu Allah kepada manusia. Pokok-pokok tersebut adalah hasil dari refleksi Gereja tentang martabat manusia berdasarkan Kitab Suci.

Dalam keterlibatan Sosial Gereja, harkat pribadi manusia menempati peran yang sentral dan menentukan. Sebagaimana ditekankan oleh Paus Yohanes XXIII dalam ensiklik Mater et Magistra (MM) bahwa prinsip pokok keterlibatan sosial Gereja adalah bahwa manusia sebagai pribadi merupakan dasar, sebab dan tujuan yang utama bagi setiap lembaga sosial. Di sanalah martabat pribadi manusia diakui dan dipertahankan. ${ }^{27}$ Kebersamaan manusia yang satu dengan manusia yang lain merupakan bentuk pertama persatuan interpersonal manusia. Hal ini mengingat bahwa dari kodratnya yang terdalam, manusia itu bersifat sosial. Manusia tidak mungkin hidup dan mengembangkan diri tanpa kehadiran sesamanya (GS art. 12). ${ }^{28}$

Setiap pribadi manusia itu berbedabeda bakat dan kemampuannya, namun Allah menganugerahkan martabat yang sama kepada setiap orang (Rerum Novarum art. 17, 24, 41). ${ }^{29}$ Martabat yang sejati itu terletak pada peri kehidupan moral yang baik. ${ }^{30}$ Manusia hidup dalam realitas sosial bersama dengan yang lain. Dengan masingmasing cara yang khas, manusia yang satu berhubungan dengan manusia lain. Seluruh umat manusia menjadi satu keluarga dan saling menghadapi dengan sikap persaudaraan dari sifat sosial manusia.

\footnotetext{
Yohanes XXIII, Mater et Magistra art. 219.

28 Koerniatmanto Soetoprawiro, Bukan Kapitalisme Bukan Sosialisme, (Yogyakarta. Kanisius, 2003), 69.

29 Koerniatmanto Soetoprawiro, Bukan Kapitalisme Bukan Sosialisme, 70.

$30 \quad$ Leo XIII, Rerum Novarum, art. 28.
}

Allah yang memelihara semua orang menghendaki agar segenap umat manusia merupakan satu keluarga, dan saling hidup dalam sikap persaudaraan. Hal ini mengingatkan bahwa cinta kasih kepada Allah dan sesama itu merupakan perintah pertama dan utama. ${ }^{31}$ Selanjutnya, dari sifat sosial manusia, tampaklah bahwa pertumbuhan pribadi manusia dan perkembangan masyarakat itu sendiri saling tergantung satu sama lain. Hal ini mengingat bahwa subjek dan tujuan semua lembaga sosial itu pada akhirnya adalah pribadi manusia itu sendiri.

Dari kodratnya, manusia memerlukan kehidupan bersama dengan sesama. ${ }^{32}$ Atas dasar sifat yang saling tergantung itulah maka muncul fenomena bonum commune atau kesejahteraan umum atau kepentingan umum. Bonum commune menempati posisi sentral, bahkan merupakan salah satu asas pokok seluruh keterlibatan sosial Gereja itu sendiri. Hal ini mengingat bahwa melalui bonum commune keunggulan martabat manusia dipertahankan. Melalui bonum commune ini, disediakan bagi manusia segala sesuatu yang dibutuhkan untuk hidup secara sungguh manusiawi.

Dengan demikian, solidaritas harus senantiasa menunjang kesejahteraan pribadi-pribadi manusia itu sendiri. Dalam kerangka itu, tata dunia yang harus semakin dikembangkan atas dasar kebenaran, dibangun dalam keadilan, dihidupkan dengan cinta kasih itu, harus menemukan keseimbangannya yang semakin manusiawi dalam kebebasan. Karena itu Gereja menekankan pentingnya sikap hormat kepada sesama. Setiap orang wajib memandang sesamanya tanpa terkecuali sebagai

\footnotetext{
$31 \quad$ Bdk. GS, art. 24

32 Bdk. GS, art. 25.
} 
dirinya yang lain. Orang wajib mengindahkan perikehidupan sesamanya beserta jerih payahnya dalam perjuangan mereka untuk hidup secara layak.

Pada gilirannya, sebagai konsekuensi logisnya adalah segala tindakan yang berlawanan dengan kehidupan itu sendiri harus diklasifikasikan sebagai tindakan yang mencoreng peradaban manusia. ${ }^{33}$ Sikap hormat dan cinta terhadap sesamanya itu harus pula mencakup mereka yang secara sosial, politik maupun religius memiliki pandangan ataupun tindakan yang berbeda. Sikap ini penting demi terselenggaranya dialog dengan mereka. Namun demikian, sikap ini tentu saja tidak dapat menjadi alasan untuk mengabaikan dan mengorbankan kebenaran dan kebaikan itu sendiri. ${ }^{34}$

Gereja mengakui adanya perbedaanperbedaan di antara manusia. Semua orang memang mempunyai kodrat serta asal muasal yang sama. Kesamaan dasariah ini harus tetap dipegang teguh. Meskipun setiap manusia memiliki kemampuan yang berbeda-beda, kesamaan martabat pribadinya menuntut dicapainya kondisi hidup yang lebih manusiawi dan adil. Perbedaan-perbedaan diantara manusia ini janganlah sampai menimbulkan batu sandungan yang berlawanan dengan keadilan sosial, kesetaraan pribadi manusia dan martabat pribadi manusia itu sendiri. ${ }^{35}$

\section{Solidaritas sebagai Upaya Membangun Kebersamaan dan Kesejahteraan Umum (Bonum Commune)}

Mgr. Johannes Pujasumarta mempunyai gagasan bahwa solidaritas berarti tekad dan keterlibatan setiap pribadi untuk

\footnotetext{
Bdk. GS, art. 27.

Bdk. GS art. 28

Bdk. GS art. 29.
}

mewujudkan kebaikan bersama (bonum commune). Solidaritas diwujudkan dalam tanggung jawab dan tindakan sosial yang berorientasi pada terwujudnya kebaikan bersama di tengah masyarakat. ${ }^{36}$ Kerjasama dan solidaritas sosial menjadi perwujudan nyata ketaatan manusia pada Allah Sang Pencipta untuk terus menerus memelihara alam dan mengelola anugerah kehidupan ini secara bertanggung jawab. ${ }^{37}$ Dalam iman Kristen, solidaritas manusia bersumber dari Injil, yakni keyakinan akan solidaritas Allah yang telah mengutus Putra-Nya untuk menyelamatkan manusia. Setiap pribadi mengemban tugas, amanat, dan tanggung jawab mengembangkan hidup bersama sebagai wujud nyata keterlibatan pada rencana Allah untuk mewujudkan keselamatan dan damai sejahtera bagi dunia. Solidaritas merupakan tuntutan hidup bermasyarakat yang didasarkan pada solidaritas kasih Allah pada manusia dan bukan sekedar sebuah sistem sosial atau ideologi politik tertentu. ${ }^{38}$

Solidaritas merupakan dasar untuk mewujudkan hidup dan pelayanan kasih, rekonsiliasi dan persahabatan. ${ }^{39}$ Solidaritas itu terarah pada amor praeferentialis pro pauperibus atau kasih yang mengutamakan orang-orang miskin. Penekanan ini didasarkan pada ajaran iman Katolik bahwa manusia merupakan gambar Allah. ${ }^{40}$ Perkembangan harus mengabdi pada kepentingan semua manusia di dunia ini. Dunia yang merupakan tempat bagi manusia untuk mengembangkan hidup dan menghayati kesatuan dengan Allah perlu dibangun

\footnotetext{
36 T. Krispurwana Cahyadi, Yohanes Paulus II: Gereja Berdialog, (Yogyakarta: Kanisius, 2011), 128-129.

37 Yohanes Paulus II, Sollicitudo Rei Socialis, art. 30.

38 B. Kieser, Solidaritas: 100 Tahun Ajaran Sosial Gereja, (Yogyakarta, Kanisius, 2010), 181.

39 T. Krispurwana Cahyadi, Yohanes Paulus II: Gereja Berdialog, 127.

$40 \quad$ Yohanes Paulus II, Sollicitudo Rei Socialis, art. 42.
} 
bersama-sama. Pembangunan dunia sebagai "taman yang luas" membutuhkan kerjasama dan solidaritas yang kuat. ${ }^{41}$ Membangun dunia yang damai dan semakin manusiawi merupakan tanggung jawab semua manusia.

Solidaritas Kristiani tampak dalam kemurahan hati, pengampunan, dan rekonsiliasi. ${ }^{42}$ Keutamaan-keutamaan itu memberi daya positif yang menopang perkembangan sejati dan hidup damai. Solidaritas antar manusia diwujudkan dalam upaya membela hak-hak asasi manusia sebagai ciptaan Allah. Dalam situasi masyarakat yang ditandai oleh kesenjangan yang tajam antara kelompok kaya dan miskin, penghargaan hak-hak asasi manusia secara nyata diwujudkan dalam tindakan membela dan membantu mereka yang miskin dan tersingkir akibat tata sosial, ekonomi dan politik yang tidak adil. Pemenuhan kebutuhan pangan, sandang, layanan kesehatan dan tempat tinggal yang layak merupakan bentuk konkrit bantuan terhadap orang-orang miskin dan tersingkir. Selain itu, layanan pendidikan bagi orangorang miskin dan tersingkir sungguh amat penting dalam kaitan dengan pemenuhan hak-hak asasi manusia secara merata dan adil

Ajaran Sosial Gereja yang termuat dalam dokumen Konsili Vatikan II, khususnya dalam Gaudium et Spes art. 31-32, menegaskan pentingnya solidaritas warga Gereja dalam membangun dan mengawal perkembangan hidup bersama. Solidaritas itu berpangkal dari penghayatan dan komitmen iman untuk menanggapi dan mencari jalan keluar terhadap masalah-masalah konkrit hidup manusia (ekonomi) demi perkembangan hidup bersama ${ }^{43}$ (GS art. 52 dan art. 85).

\footnotetext{
Yohanes Paulus II, Sollicitudo Rei Socialis, art. 29.

Yohanes Paulus II, Sollicitudo Rei Socialis, art. 40.

CB. Mulyatno, "Solidaritas dan Perdamaian Dunia dalam
}

Solidaritas berhubungan erat perjuangan membela martabat hidup manusia dan perwujudan penyelamatan Allah dalam dunia dalam hidup bersama yang adil, bersaudara, saling mengasihi dan damai.

Ensiklik Sollicitudo Rei Socialis (SRS) ditulis dalam rangka peringatan 20 tahun Ensiklik Populorum Progressio (PP) oleh Paus Paulus VI. PP berbicara mengenai pembangunan manusia dan harapan untuk kemajuan dunia. PP merupakan penjelasan dan penegasan ajaran Konsili Vatikan II, terutama yang tertulis dalam Gaudium et Spes, mengenai kehidupan manusia di tengah dunia. Pembangunan manusia harus dilaksanakan secara utuh dan menyeluruh. Secara khusus PP menegaskan bahwa pembangunan bangsa-bangsa harus memberi perhatian pada pembebasan manusia dari kelaparan, kesengsaraan (miskin), penyakit dan kebodohan. ${ }^{44}$ Seruan Ensiklik SRS merupakan undangan dan dorongan moral bagi warga Gereja untuk bertindak secara sosial demi meringankan beban orang-orang miskin $^{45}$. Dengan kata lain, warga Gereja didorong untuk peduli atau solider terhadap orang-orang miskin dan meringankan beban hidup mereka secara nyata.

Prinsip solidaritas mencakup keyakinan bahwa setiap pribadi membutuhkan sesama dan setiap pribadi bertanggungjawab terhadap perkembangan diri dan hidup bersama. ${ }^{46}$ Dalam perspektif Ajaran Sosial Gereja (ASG), solidaritas merupakan panggilan setiap orang untuk mewujudkan tanggung jawab sosial dalam mengembangkan hidup bersama

Sollicitudo Rei Socialis", Jurnal Teologi Vol. 4 No. 2 (2015) [jurnal online], tersedia dari https://e-journal.usd.ac.id/index. php/jt/article/view/470; diakses 5 Mei 2020.

44 B. Kieser, Solidaritas: 100 Tahun Ajaran Gereja, 185-186.

45 Yohanes Paulus II, Sollicitudo Rei Socialis, art. 13.

46 B. Kieser, Solidaritas: 100 Tahun Ajaran Sosial Gereja, 14. 
secara manusiawi dan menyeluruh. Iman membarui komitmen untuk bekerjasama dan mewujudkan solidaritas sosial secara terus menerus agar perkembangan dunia semakin manusiawi. Di tengah kompleksnya persoalan dunia ini, SRS menggarisbawahi pentingnya solidaritas di tengah berbagai persoalan sosial. Ada beberapa persoalan sosial yang menjadi tanda lemahnya solidaritas dan menantang warga Gereja untuk membarui komitmen imannya. Kesenjangan antara yang kaya dan miskin semakin besar; ${ }^{47}$ kesenjangan antara orangorang kaya dan miskin diakibatkan oleh lunturnya solidaritas; masing-masing negara dan kelompok berpusat pada kepentingan diri dan menutup mata pada kepentingan lebih luas. $^{48}$

\section{Solidaritas sebagai Pilihan Iman demi Pewartaan Kerajaan Allah}

Dalam solidaritas, rumusan pilihan mendahulukan kaum miskin (preferential option for the poor) bukanlah rumusan biblis. Yang dapat ditemukan dalam Kitab Suci adalah unsur-unsur gagasan yang menunjukkan pemihakan terhadap kaum miskin. Sangatlah mencolok dalam Kitab Suci gambar orang miskin dan kemiskinan dalam hubungan dengan Allah. Allah digambarkan sebagai Allah yang memperhatikan, melindungi, membela orang miskin dan malang. Keberpihakan pada kaum miskin tampak dalam pemihakan Allah pada kelompok budak tertindas di Mesir (Ul 7:7-8). Karya pembebasan dari Mesir menunjukkan karya Allah yang membela umat-Nya yang tertindas (Ul 26:510; Bil 20:14-21). Para nabi secara sangat jelas menampakkan keberpihakan mereka kepada kaum miskin lewat kritik-kritik keras

47 Yohanes Paulus II, Sollicitudo Rei Socialis, art. 12-14.

48 Yohanes Paulus II, Sollicitudo Rei Socialis, art. 20-23. mereka kepada penguasa yang menindas. Yesus juga menampakan keberpihakan ini, tidak hanya dengan memperjuangkan kepentingan-kepentingan kaum miskin melainkan dengan cara hidup-Nya sebagai orang miskin.

Lukas menampilkan Yesus sebagai satu dari antara manusia miskin. Sebagai orang miskin, Yesus menunjukkan solidaritasNya dengan kaum miskin yang lain. Kemiskinan Yesus ditampilkan sejak awal pewartaan tentang Yesus. Malaikat Gabriel mewartakan kepada Maria dari Nazareth bahwa ia akan mengandung dan melahirkan Yesus (Luk 1: 28-31). Maria menjadi gambar kemiskinan karena ia dari Nazareth, dan karena ia adalah wanita. Dalam masyarakat Yahudi yaitu dalam tata masyarakat yang patriarkat, kedudukan wanita lebih rendah dibandingkan laki-laki. Hal ini menunjukkan bahwa wanita menjadi kelompok tertindas yang diabaikan kehadirannya. Yesus sendiri lahir di kandang dan dibaringkan dalam palungan (Luk 2:7). Orang-orang yang mengunjunginya adalah para gembala yang menggembalakan kawanan domba di padang (Luk 2:16). Lukas mau menekankan bahwa fakta kemiskinan Yesus dan arti hidup-Nya merupakan harapan bagi kaum miskin. ${ }^{49}$ Pemihakan Yesus kepada kaum miskin mulai sejak permulaan karya-Nya di Sinagoga Nazareth. Di Sinagoga Nazareth Yesus menyatakan bahwa kepada kaum miskinlah warta gembira dinyatakan (Luk 4:18-19).

Yesus mewartakan diri sebagai utusan yang diwartakan oleh para nabi dan sekaligus yang sama menjelaskan bahwa misi-Nya ditujukan kepada mereka yang malang dan miskin. ${ }^{50}$ Paulus menekankan bagaimana

\footnotetext{
$49 \quad$ Clodovis Boff dan Jorge Pixley, The Bible, The Church, and The Poor, (Michigan: Orbis Book, 1989), 59.

50 Julio de Santa Ana, Good News to The Poor, (New York: Orbis Books, 1979), 13.
} 
Yesus yang kaya justru mengenakan kemiskinan sebagai cara hidup-Nya. "Karena kamu telah mengenal kasih karunia Tuhan kita Yesus Kristus, bahwa Ia yang oleh karena kamu menjadi miskin, sekalipun Ia kaya, supaya kamu menjadi kaya oleh karena kemiskinan-Nya” (2 Kor 8:9). Dengan solidaritas-Nya terhadap kaum miskin, Yesus mau membebaskan mereka dari situasi penindasan yang menimpa mereka. Dalam solidaritas-Nya, Ia menempatkan diri sebagai hamba. Model hidup seorang hamba rupanya menjadi model hidup yang dipilih oleh Yesus dan Ia memberi teladan agar para murid-Nya menjadi hamba satu sama lain (Yoh 13:14-15).

Yesus lahir, hidup dan wafat dalam kemiskinan. Yesus mencintai kaum miskin dan mengidentifikasikan diri-Nya dengan mereka. Yesus mengidentifikasi diri-Nya dengan mereka yang lapar dan haus, yang sakit, yang telanjang, para tahanan dan mereka yang menjadi orang asing dan tidak mempunyai tempat tinggal. Karena itu ada hubungan yang sangat dekat antara Yesus dan kaum miskin. Kisah penghakiman terakhir dalam Mat 25:31-46 menunjukkan kedekatan Yesus dengan kaum miskin. Yesus mengidentifikasikan diri-Nya dengan mereka yang miskin dengan mengatakan, "Sesungguhnya segala sesuatu yang kamu lakukan untuk salah seorang dari saudara$\mathrm{Ku}$ yang paling hina ini, kamu telah melakukannya untuk Aku" (Mat 25:40).

Dalam pemahaman sekarang, pilihan mendahulukan kaum miskin sudah merupakan suatu perintah, komitmen, atau pun misi Gereja. Dengan demikian, pilihan ini mesti ditempatkan dalam bidang etik dan praktek pastoral. Akan tetapi sebelum menjadi suatu komitmen bagi Gereja, pilihan mendahulukan kaum miskin merupakan sebuah realitas iman, sebuah kebenaran teologis. Realitas iman ini ditemukan dalam Kitab Suci. Realitas iman ini mulai dari karya Allah dalam sejarah keselamatan. Allah memaksudkan sejarah keselamatan bagi semua orang, tetapi terutama bagi mereka yang miskin dan tertindas. Yang pertama-tama menentukan suatu pilihan untuk mendahulukan kaum miskin adalah Allah. Gereja yang mengimani Allah menghidupi juga pilihan tersebut. Maka Allah-lah yang pertama-tama memilih mendahulukan kaum miskin; sementara bagi Gereja pilihan mendahulukan kaum miskin merupakan konsekuensi atas pilihannya untuk mengimani Allah yang memilih mendahulukan kaum miskin. ${ }^{51}$

Dengan demikian, pilihan Gereja untuk mendahulukan kaum miskin bukanlah sekedar sebuah pilihan etis-politis dari sekian macam alternatif. Pilihan mendahulukan kaum miskin adalah pilihan iman. Pilihan tersebut berakar pada pilihan Allah sendiri. Tanpa diakarkan pada misteri Allah, pilihan mendahulukan kaum miskin hanya menjadi tulisan atau kata-kata semata, tanpa jaminan kekuatan untuk melawan macam-macam bahaya kekaburan dan kemandegan. ${ }^{52}$ Iman memberikan pembenaran tertinggi bagi pilihan ini dengan menunjukkan bahwa pilihan itu berakar pada misteri Allah sendiri yang pada hakekatnya adalah misteri kasih dan kemerdekaan.

Kadang muncul pertanyaan, apakah pilihan mendahulukan kaum miskin tidak bertentangan dengan universalitas karya keselamatan Allah? Karya keselamatan Allah tetaplah bersifat universal, akan tetapi universalitas itu membutuhkan kualifikasi.

\footnotetext{
Clodovis Boff dan Jorge Pixley, The Bible, The Church, and The Poor, 109.

52 Clodovis Boff dan Jorge Pixley, The Bible, The Church, and The Poor, 109.
} 
Kisah Kitab Suci menampilkan bahwa ungkapan konkret karya keselamatan Allah adalah kasih-Nya yang dicurahkan kepada kaum budak Mesir. Dalam hidup Yesus maupun jemaat yang tumbuh di sekitar Yesus, orang kaya tidak dikecualikan dari rencana penyelamatan Allah. ${ }^{53}$ Pilihan mendahulukan kaum miskin bukanlah pilihan untuk mengeksklusifkan orang kaya dari rencana penyelamatan Allah. Pilihan ini merupakan sikap dan tindakan Gereja untuk mengikuti Yesus yang mewartakan Kerajaan Allah dengan mendahulukan mereka yang setengah mati, tidak berdaya, dan tanpa pertolongan.

Memilih Yesus berarti memilih apa yang Dia pilih dan perjuangkan, yakni kaum miskin. Pilihan mendahulukan kaum miskin bukanlah pilihan yang ditambahkan pada iman Kristen. Hal ini berarti bahwa pilihan mendahulukan kaum miskin merupakan pilihan teologis (lebih spesifik lagi - pilihan kristologis). Identitas pilihan kristen berakar pada iman kristologis. Inilah yang membedakan pilihan kristiani dari pilihan kelompok-kelompok atau gerakan-gerakan sosial lain. Bagi orang Kristen, pilihan mendahulukan kaum miskin bukanlah pilihan pertama. Pilihan ini senantiasa berasal dari pilihan untuk mengimani Yesus. Pilihan akan Yesus dan pilihan akan orang miskin merupakan dua dimensi dari satu komitmen yang sama. ${ }^{54}$ Karena itu, motivasi utama pilihan mendahulukan kaum miskin ditemukan dalam iman akan Kristus. Keyakinan sentral iman kristiani akan pemihakan kepada kaum miskin mengalir sebagai tanggapan atas cinta yang ditunjukkan oleh Allah kepada manusia

\footnotetext{
53 Clodovis Boff dan Jorge Pixley, The Bible, The Church, and The Poor, 115.

54 Clodovis Boff dan Jorge Pixley, The Bible, The Church, and The Poor, 115.
}

dalam peristiwa keselamatan Yesus Kristus. Dalam praktek hidup beriman senantiasa ditemukan antara pilihan (iman) akan Yesus Kristus dan komitmen (politik) terhadap kaum miskin. Iman kepada Yesus melibatkan manusia pada kaum miskin; komitmen pada kaum miskin mengantar orang beriman ke dalam misteri Kristus yang lebih dalam. ${ }^{55}$

Pokok pewartaan Yesus bukanlah tentang diri-Nya sendiri, tetapi lebih dari itu adalah tentang Kerajaan Allah. Kerajaan Allah menjadi sentral pewartaan dan karya Yesus. Misinya adalah untuk menghadirkan Kerajaan Allah dan mengundang orangorang untuk memasukinya. Melalui sabda dan karya-Nya, tanda-tanda dan mujizat, dan melalui teladan serta sikap-Nya terhadap bermacam-macam orang, Yesus mewartakan Kerajaan Allah tersebut. Pewartaan Yesus tentang Kerajaan Allah ini menuntut sikap yang jelas yakni mengarahkan diri kepada Allah. Pewartakan Kerajaan Allah menuntut pertobatan. Pertobatan bukan hanya kembali kepada Allah melainkan juga mengarahkan diri seutuhnya kepada Allah sebagai tanggapan, penerimaan akan Allah yang memerintah dan berkuasa.

Dalam Lumen Gentium art. 5, menampakkan keterkaitan erat antara Yesus dan Kerajaan Allah. Kerajaan Allah itu menampakkan diri kepada orang-orang dalam sabda, karya dan kehadiran Yesus. Kerajaan Allah terutama tampil dalam pribadi Kristus sendiri, Putera Allah dan Putera manusia yang datang "untuk melayani dan memberikan nyawa-Nya menjadi tebusan bagi banyak orang" (Mrk 10:45).

Mewartakan Kerajaan Allah mengandung aspek soteriologis, teologis, eskatologis, dan

55 Clodovis Boff dan Jorge Pixley, The Bible, The Church, and The Poor, 116. 
kristologis. Kerajaan Allah ada dalam lingkup penyelamatan sebagai peristiwa atau situasi penyelamatan. Kerajaan Allah merupakan situasi dan peristiwa penyelamatan sepenuhnya. Kerajaan Allah yang akan datang merupakan lingkup keselamatan yang dikatakan dan dijanjikan kepada mereka yang menderita, kaum miskin, dan pendosa. Tindakan Allah untuk mewujudkan Kerajaan Allah itu diwujudkan dengan mendahulukan mereka yang paling menderita, yang paling jauh dari keselamatan.

Keselamatan yang dibawa oleh Allah mengatasi penderitaan dalam segala bentuk dan dimensinya. Keselamatan atau pembebasan tidak hanya bersifat batiniah, melainkan juga jasmaniah-material. Pewartaan tentang Kerajaan Allah oleh Yesus melahirkan secara baru siapakah Allah itu. Pewartaan baru tentang Allah sangat dipengaruhi oleh pengalaman hubungan pribadi Yesus dengan Allah. Allah dialami oleh Yesus sebagai Abba, Bapa tercinta. Dia adalah Bapa yang murah hati, maha pengampun, dan berbelas kasih. Dia mencintai manusia tanpa syarat dan menarik semua manusia kepada-Nya. Maka Allah adalah Bapa semua orang tanpa mengecualikan siapapun. Mengakui Allah sebagai Bapa berarti mengakui pula semua orang sebagai saudara-saudari dalam keluarga Allah yang satu dan sama. Yang dicita-citakan adalah persaudaraan umat manusia terjadi begitu rupa sehingga tidak ada yang kelaparan dan berkelimpahan, tidak ada yang terlantar dan yang tak acuh, tidak ada yang dihisap dan yang menghisap.

Kerajaan Allah yang diwartakan oleh Yesus tidak berhenti di dunia ini. Kerajaan Allah sudah dan sedang terwujud pada zaman sekarang ini menuju kepenuhannya pada akhir zaman. Sekarang ini, Kerajaan Allah mewujudkan diri secara dinamis menuju kepenuhannya. Pembebasan sepenuhnya sudah mulai dengan peristiwa Yesus, tetapi belum selesai karena masih merupakan harapan eskatologis, harapan yang akan terpenuhi pada akhir zaman. Kerajaan Allah sudah dan sedang terwujud pada zaman sekarang ini tetapi belum sepenuhnya terpenuhi. Kerajaan Allah terwujud dalam gerakan dan tindakan manusia tetapi tidak dapat direduksi menjadi gambaran manusiawi yang terbatas. Kerajaan Allah senantiasa memuat perspektif masa depan. Salah satu pokok tekanan pewartaan Kerajaan Allah oleh Yesus adalah pewartaan kepada kaum miskin. Yesus mengatakan bahwa kaum miskin adalah yang mempunyai Kerajaan Allah. Tentu saja yang dimaksud kaum miskin adalah orang-orang yang hidup dalam kemiskinan material dan terbelenggu oleh bermacam-macam ketidakadilan religius-politis yang dilakukan baik oleh penguasa Yahudi maupun oleh penguasa Romawi pada saat itu. Yesus mengalamatkan pewartaan-Nya tentang Kerajaan Allah kepada kaum miskin, "Berbahagialah hai kamu yang miskin karena kamulah yang empunya Kerajaan Allah” (Luk 6:20). Orang miskin disebut berbahagia karena mereka menerima Kerajaan Allah yang saat itu sudah terwujud dalam pribadi Yesus sendiri.

Yesus mengosongkan diri dan mengambil rupa seorang hamba dan menjadi sama dengan manusia. Dengan demikian nyatalah bahwa Allah dalam diri Yesus mengambil keadaan manusia yang miskin (hamba) sebagai cara keberadaan dan kehadiran Allah di tengah-tengah manusia. Peristiwa inkarnasi menunjukkan bahwa manusia Yesus yang miskin itu merupakan pewahyuan Allah dan Yesus itulah yang menyelamatkan 
dunia. ${ }^{56}$ Kemiskinan bukanlah sesuatu yang kebetulan dalam pribadi Yesus. Kemiskinan merupakan bagian integral dari perendahan diri dan pengosongan diri Yesus. ${ }^{57}$

Mengapa Allah memilih kaum miskin dan bahkan dalam diri Yesus mengidentikkan diri dengan mereka? Pilihan ini terkait erat dengan Allah yang diwartakan dalam Kitab Suci. Allah yang diwartakan adalah Allah yang adil. Sementara itu, kaum miskin adalah orang-orang yang mengalami kehidupan paling tidak adil. Mereka dirugikan dan selalu ditindas. Mereka menjadi orangorang tak berwajah, tak bersuara, dan tanpa perlindungan. Allah berpihak pada mereka dan menjadi perlindungan mereka. Apa yang menggerakkan Allah untuk berpihak kepada mereka yang tertindas bukanlah ketidakadilan manusia akan tetapi kebenaran mereka yang ditindas demi penegakan keadilan dalam sejarah. ${ }^{58}$ Allah tidak menyatakan diri dalam wujud penguasa ataupun tuan tanah yang kaya. Allah menyatakan diri dalam manusia yang telah tampil sebagai Allah yang miskin; bukan sebagai Allah yang kaya. Dalam diri kaum miskin, Allah dijumpai persis di dalam kemiskinan. Berhadapan dengan kaum miskin berarti diundang untuk mencintai, melayani, solider dan untuk bertindak adil.

\section{Solidaritas sebagai Karya Pastoral Gereja}

Dalam iman Kristen, solidaritas manusia bersumber dari Injil, yakni keyakinan akan solidaritas Allah yang telah mengutus Putra-Nya untuk menyelamatkan manusia. Dengan demikian, pilihan Gereja untuk

\footnotetext{
56 Clodovis Boff dan Jorge Pixley, The Bible, The Church, and The Poor, 110.

57 Clodovis Boff dan Jorge Pixley, The Bible, The Church, and The Poor, 110.

58 Clodovis Boff dan Jorge Pixley, The Bible, The Church, and The Poor, 113.
}

mendahulukan kaum miskin bukanlah sekedar sebuah pilihan etis-politis dari sekian macam alternatif. Pilihan mendahulukan kaum miskin adalah pilihan iman. Pilihan tersebut berakar pada pilihan Allah sendiri. Rasul Yakobus berkata, "Sebab seperti tubuh tanpa roh adalah mati, demikian jugalah iman tanpa perbuatan adalan mati" (Yakobus 2:26). Karena itulah pilihan tersebut hendaknya tidak hanya berhenti pada iman, tetapi perlu diwujudkan dalam tindakan pelayanan, sebagaimana Yesus sendiri yang melayani kaum miskin dalam karya-Nya mewartakan Kerajaan Allah (Mat 5:1-12). Dalam Dei Verbum art. 5, dikatakan bahwa kepada Allah yang menyampaikan wahyu, manusia wajib menyatakan "ketaatan iman" (Rom 16:26; Rom 1:5; 2 Kor 10:5-6). Beriman menjadi nyata jika orang mengusahakan kesejahteraan dan kebahagiaan sesama, yaitu bertindak dan bertanggungjawab demi kepentingan bersama (solidaritas).

Solidaritas harus sampai pada pilihan mendahulukan kaum miskin. Pilihan mendahulukan kaum miskin sebagai tuntutan etis maupun praktis tidak begitu saja dapat dilaksanakan dalam praksis pastoral Gereja. Pilihan tersebut mesti dikonkretkan dalam pilihan pilihan tindakan dan perencanaan praktis pastoral Gereja. Yang dimaksudkan di sini adalah seluruh tugas pelayanan yang dilaksanakan oleh semua warga Gereja (khususnya mereka yang diberi tanggung jawab untuk menangani pelayanan tertentu dalam Gereja) demi kepentingan seluruh Gereja. Dengan demikian pastoral tidak terbatas pada tugas pelayanan yang dilakukan oleh hierarki.

Solidaritas dengan pilihan mendahulukan kaum miskin merupakan pilihan hidup 
Gereja agar berupaya secara khusus demi terwujudnya keadilan sosial bagi berjutajuta orang yang belum memperoleh sandang pangan, papan, pelayanan kesehatan pendidikan, pekerjaan, dan kebutuhan kebutuhan dasar yang lain. Pilihan tersebut berkaitan dengan permasalahan konkret umat manusia yang dilanda kemiskinan. Berbicara tentang kemiskinan adalah berbicara tentang orang-orang miskin yang konkret. Gereja yang menyatakan solidaritasnya dengan pilihan untuk mendahulukan kaum miskin adalah mengusahakan agar semua bidang kegiatannya (liturgi, koinonia, diakonia, kerygma, dan martyria) digerakkan oleh dan diarahkan pada pelayanan bagi mereka yang miskin dan menderita. Dalam semua kegiatannya, kaum miskin menjadi sentral perhatian Gereja.

Tantangan tersebut tentu menuntut perencanaan yang matang. Solidaritas Gereja dengan mendahulukan kaum miskin mengantar Gereja pada pilihan tindakan dalam dimensi politis untuk mengusahakan transformasi struktur-struktur sosial menuju masyarakatyangsemakin adil. Opsipemihakan terhadap kaum miskin menjadi objek politis yang merupakan pengejawantahan kasih Kristiani secara baru. Clodovis Boff dan Jorge Pixley menyebutnya sebagai political love. ${ }^{59}$ Pemilihan ini melibatkan upaya konsientisasi, pengorganisasian, dan gerakan kaum miskin serta semua yang berpihak kepada mereka. Berpihak kepada kaum miskin berarti menempatkan diri pada sisi kaum miskin, dalam solidaritas dengan mereka dalam perjuangan dan kepentingan mereka; bukan untuk membuat kaum miskin sebagai sesama kita tetapi untuk menjadikan diri kita sahabat bagi mereka. ${ }^{60}$

\footnotetext{
59 Clodovis Boff dan Jorge Pixley, The Bible, The Church, and The Poor, 222

60 Clodovis Boff dan Jorge Pixley, The Bible, The Church, and The Poor, 222
}

Dalam Konsili Vatikan II, hidup sakramental yang berpuncak pada liturgi merupakan sumber dan puncak doa personal maupun keterlibatan apostolis. ${ }^{61}$ Tetapi teologi pasca Konsili Vatikan II, ada perkembangan pemahaman bahwa keterlibatan sosio-politis terutama bagi kaum miskin merupakan sumber dan puncak. Konsili Vatikan II, teologi pasca Konsili Vatikan II, menolak dualisme yang memisahkan spiritualitas dalam kontemplasi (doa) dan aksi. Keduanya samasama merupakan hal yang penting. Misi profetik untuk mewartakan sabda menuntut spiritualitas "mendengarkan" suara Allah di tengah-tengah aktifitas apostolis. Dengan demikian Gereja perlu menegaskan kembali semua lingkup kegiatannya seraya menempatkan kaum miskin sebagai prioritas utama pelayanannya. Gereja dituntut untuk memenuhi harapan kaum miskin akan dunia yang lebih baik terutama ketika mereka sungguh-sungguh menderita ada putus asa.

\section{PENUTUP}

Pokok-pokok atau nilai-nilai solidaritas sungguh hidup dalam pemikiran Mgr. Johannes Pujasumarta. Nilai-nilai solidaritas dalam Ajaran Sosial Gereja menjadi dasar pemikiran dan dalam karya pelayanan Mgr. Johannes Pujasumarta terhadap mereka yang lemah, miskin, tersingkir dan difabel. Dalam pemikiran solidaritasnya, Mgr. Johannes Pujasumarta tidak hanya menyoroti kepedulian kepada sesama, tetapi juga seluruh ciptaan. Solidaritas adalah tekad yang teguh dan tegar, mengabdikan diri pada kebaikan bersama, dan bertanggungjawab atas semua. Solidaritas harus sampai pada pilihan mendahulukan kaum miskin dan diwujudkan dalam tindakan sosial

\footnotetext{
Bdk. SC, art. 10.
} 
yang berorientasi pada terwujudnya kesejahteraan umum (bonum commune) di tengah masyarakat. Solidaritas merupakan sikap dasar setiap pribadi sebagai makhluk sosial yang memiliki martabat yang sama sebagai ciptaan Allah. Solidaritas merupakan pilihan iman yang bersumber pada pilihan Allah sendiri yang menyelamatkan seluruh ciptaan. Setiap pribadi merupakan saudara bagi sesama manusia. Kerjasama dan solidaritas sosial menjadi perwujudan nyata ketaatan manusia pada Allah Sang Pencipta

\section{DAFTAR RUJUKAN}

Ana, De Santa, Julio. Good News to The Poor. New York: Orbis Books, 1979.

Boff, Clodovis \& Pixley, Jorge. The Bible, The Church, and The Poor. Michigan: Orbis Book, 1989.

Cahyadi, Krispurwana, T. Yohanes Paulus II: Gereja Berdialog. Yogyakarta: Kanisius, 2011.

Depdiknas. Kamus Besar Bahasa Indonesia. Jakarta: Pusat Bahasa, 2008.

Gunawan, Y. Menghidupi Teologi Berkah Bersama Mgr. Johannes Pujasumarta. Yogyakarta: Kanisius, 2018.

Kieser, B. Solidaritas 100 tahun Ajaran Sosial Gereja. Yogyakarta: Kanisius, 1992.

Mulyatno, CB. "Solidaritas dan Perdamaian Dunia dalam Sollicitudo Rei Socialis". Jurnal Teologi Vol. 4 No. 2 (2015), 121132.

Paulus VI. Populorum Progressio. (diterjemahkan oleh S. Alfons Suhardi). Jakarta: Departemen Dokumentasi dan Penerangan KWI, 1994.

Pujasumarta, J. Surat Gembala Prapaskah 2011 Keuskupan Agung Semarang. Semarang: 25 Februari 2011.

Pujasumarta, J. Surat Gembala Hari Pangan Sedunia tahun 2011 Keuskupan Agung Semarang. Semarang: 25 September 2011.

Pujasumarta, J. Surat Gembala HUT Kemerdekaan Ke-67 Republik Indonesia. Semarang: 10 Agustus 2012. dan Sang Penyelamat untuk terus-menerus memelihara alam dan mengelola anugerah kehidupan ini secara bertanggungjawab. Karena itu, solidaritas adalah satu-satunya jalan untuk keberlangsungan sebuah kehidupan bersama. Maka solidaritas bukan hanya sebuah "keutamaan sosial dan moral" kristiani, melainkan sebuah keharusan eksistensial yang harus ada dalam sebuah komunitas, masyarakat, dan bangsa. Solidaritas adalah sebuah kebutuhan dasar manusia.

Pujasumarta, J. Surat Gembala Hari Minggu Hubungan Antaragama dan Kepercayaan 2013 Keuskupan Agung Semarang. Semarang: 20 Januari 2013.

Pujasumarta, J. Surat Gembala Hari Raya Kemerdekaan RI ke-68: Mengisi Kemerdekaan dengan Peradaban Kasih. Semarang: 15 Agustus 2013.

Pujasumarta, J. Surat Gembala Hari Minggu Hubungan Antaragama dan Kepercayaan 2014 Keuskupan Agung Semarang. Semarang: 19 Januari 2014.

Pujasumarta, J. Surat Gembala Prapaskah 2014 Keuskupan Agung Semarang. Semarang: 22 Februari 2014.

Pujasumarta, J. Surat Gembala Prapaskah 2015 Keuskupan Agung Semarang. Semarang: 2 Februari 2015.

Pujasumarta, J. Surat Gembala Hari Pangan Sedunia 2015 Keuskupan Agung Semarang . Semarang: 28 September 2015.

Soetoprawiro, Koerniatmanto, Bukan Kapitalisme Bukan Sosialisme. Yogyakarta: Kanisius, 2003.

Suseno, Magnis, Frans. Berfilsafat dari Konteks. Jakarta: Gramedia, 1991.

Widi, Nur, M. Eklesiologi ARDAS Keuskupan Agung Semarang. Yogyakarta: Kanisius, 2009.

Yohanes Paulus II, Sollicitudo Rei Socialis. (diterjemahkan oleh P. Turang). Jakarta: Sekretariat Keadilan dan Perdamaian KWI, 1994. 
Yohanes XXIII, Mater et Magistra. (diterjemahkan oleh R. Hardawiryana). Jakarta: Departemen Dokumentasi dan Penerangan KWI, 1994.

Dokumen Konsili Vatikan II. (diterjemahkan oleh R. Hardawiryana). Jakarta: Obor, 2008
Kumpulan Dokumen Ajaran Sosial Gereja Tahun 1891-1991: dari Rerum Novarum sampai Centesimus Annus. (diterjemahkan oleh R. Hardawiryana). Jakarta: Departemen Dokumentasi dan Penerangan KWI, 1999. 